\title{
Carbon balance of South Asia constrained by passenger aircraft $\mathrm{CO}_{2}$ measurements
}

\author{
P. K. Patra ${ }^{1}$, Y. Niwa ${ }^{2}$, T. J. Schuck ${ }^{3}$, C. A. M. Brenninkmeijer ${ }^{3}$, T. Machida ${ }^{4}$, H. Matsueda ${ }^{2}$, and Y. Sawa ${ }^{2}$ \\ ${ }^{1}$ Research Institute for Global Change, JAMSTEC, Yokohama 236 001, Japan \\ ${ }^{2}$ Meteorological Research Institute, Tsukuba, Ibaraki, 305-0052 Japan \\ ${ }^{3}$ Max Planck Institute for Chemistry, 55128 Mainz, Germany \\ ${ }^{4}$ National Institute for Environmental Studies, Tsukuba, Ibaraki, 305-0052 Japan
}

Received: 14 January 2011 - Published in Atmos. Chem. Phys. Discuss.: 14 February 2011

Revised: 2 May 2011 - Accepted: 3 May 2011 - Published: 6 May 2011

\begin{abstract}
Quantifying the fluxes of carbon dioxide $\left(\mathrm{CO}_{2}\right)$ between the atmosphere and terrestrial ecosystems in all their diversity, across the continents, is important and urgent for implementing effective mitigating policies. Whereas much is known for Europe and North America for instance, in comparison, South Asia, with 1.6 billion inhabitants and considerable $\mathrm{CO}_{2}$ fluxes, remained terra incognita in this respect. We use regional measurements of atmospheric $\mathrm{CO}_{2}$ aboard a Lufthansa passenger aircraft between Frankfurt (Germany) and Chennai (India) at cruise altitude, in addition to the existing network sites for 2008, to estimate monthly fluxes for 64regions using Bayesian inversion and transport model simulations. The applicability of the model's transport parameterization is confirmed using $\mathrm{SF}_{6}, \mathrm{CH}_{4}$ and $\mathrm{N}_{2} \mathrm{O}$ simulations for the CARIBIC datasets. The annual amplitude of carbon flux obtained by including the aircraft data is twice as large as the fluxes simulated by a terrestrial ecosystem model that was applied to prescribe the fluxes used in the inversions. It is shown that South Asia sequestered carbon at a rate of $0.37 \pm 0.20 \mathrm{Pg} \mathrm{Cyr}^{-1}\left(1 \mathrm{PgC}=10^{15} \mathrm{~g}\right.$ of carbon in $\mathrm{CO}_{2}$ ) for the years 2007 and 2008. The seasonality and the strength of the calculated monthly fluxes are successfully validated using independent measurements of vertical $\mathrm{CO}_{2}$ profiles over Delhi and spatial variations at cruising altitude over Asia aboard Japan Airlines passenger aircraft.
\end{abstract}

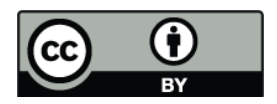

Correspondence to: P. K. Patra (prabir@jamstec.go.jp)

\section{Introduction}

Quantification of the Earth's terrestrial carbon fluxes is a highly complex task. Although the fluxes of $\mathrm{CO}_{2}$ due to the combustion of fossil fuels are reasonably well known, the behavior of the biosphere in all its diversity is still subject to intensive research. Because of extensive research projects using a variety of measurement and model approaches, the fluxes for the USA and Europe are best known (Pacala et al., 2001; Janssens et al., 2003; Schulze et al., 2010), and recently components of carbon fluxes were analyzed for China, Amazonia and Africa (Piao et al., 2009; Malhi et al., 2009; Castaldi et al., 2010). In all cases measurements of atmospheric $\mathrm{CO}_{2}$ prove indispensable, and indeed data collected from surface observatories, small aircraft, flux towers, and satellites are increasingly used. However, much of Asia (except South Korea and Japan), Africa and South America still lack routine measurements of $\mathrm{CO}_{2}$ and other greenhouse gases, which are required for estimating surface fluxes using data inversion or assimilation models (WDCGG, 2010; GLOBALVIEW-CO 2 , 2009). Only recently, two aircraft measurement programs produce large scale coverage of in situ $\mathrm{CO}_{2}$ measurements, namely, CARIBIC: Civil Aircraft for the Regular Investigation of the atmosphere Based on an Instrument Container (Brenninkmeijer et al., 2007), and CONTRAIL: Comprehensive Observation Network for TRace gases by AIrLiner (Machida et al., 2008; Matsueda et al., 2008). Results from these 2 projects are now being used for understanding the relative role of surface fluxes and atmospheric transport in simulating $\mathrm{CO}_{2}$ concentrations over major airports and in the upper troposphere (see for example Niwa et al., 2011 for the extensive use of CONTRAIL data for evaluating multiple transport model simulations).

India, by far the largest country in South Asia, has with about 1.2 billion inhabitants the 2 nd largest population in

Published by Copernicus Publications on behalf of the European Geosciences Union. 
the world, and due to rapid economic growth its $\mathrm{CO}_{2}$ emission due to fossil fuel consumption stood third largest with $0.44 \mathrm{PgC} \mathrm{yr}^{-1}$ in 2007 (Boden et al., 2010). Global $\mathrm{CO}_{2}$ release due to fossil fuel usage is estimated to have been $7.7 \pm 0.4 \mathrm{PgC}^{-1}$ for the period of 2000-2008, which was balanced by an atmospheric accumulation of $4.1 \pm 0.1 \mathrm{Pg} \mathrm{C} \mathrm{yr}^{-1}$ and an uptake of $3.6 \pm 0.9 \mathrm{Pg} \mathrm{C} \mathrm{yr}^{-1}$ by land and ocean (LeQuere et al., 2009). Great efforts are made to reduce the uncertainty of the regional carbon budgets to reduce the uncertainty in uptake (or release) by the earth's ecosystems. The carbon balance of South Asia, comprising of India and its adjacent countries Bangladesh, Nepal and Pakistan is however poorly researched, mainly due to lack of observational data. This now changes as witnessed by recent greenhouse gas studies, using regional measurements (Bhattacharya et al., 2009; Schuck et al., 2010; Assonov et al., 2010) or remote sensing (e.g., Park et al., 2007; Xiong et al., 2009). However, numerical modeling studies for verifying regional sources and sinks have not yet been done systematically. Unlike for the case of China, Europe or the US, inversion based estimations of surface fluxes for South Asia are poorly constrained with Cape Rama, at the southwest coast of India being the only measurement site for this purpose (Rayner et al., 2008; Patra et al., 2009b; Bhattacharya et al., 2009).

Throughout the year, large changes in fluxes occur because this region experiences unique climate dynamics governed by the southwest monsoon in summer (June-September), when South Asia collects $70-80 \%$ of its annual rainfall, and the "western disturbances", which bring moderate rainfall $(\sim 12 \%$ of annual total over Delhi area) and warm weather to the northern part of the subcontinent in winter (December-March) (Pisharty and Desai, 1956; Parthasarathy et al., 1994). The western disturbances are important for the development of the winter crop in the northern subcontinent, which includes the locally important staple wheat, while the summer monsoon is essential for the main crop production in most parts of South Asia, especially rice cultivation. Forests are expected to be most active in sequestering $\mathrm{CO}_{2}$ following the intense monsoonal rain in the predominantly tropical climate.

\section{Materials and methods}

\subsection{Forward and inverse models}

We use an atmospheric general circulation model (AGCM)based chemistry transport model (ACTM) (Patra et al., 2009a) and a time-dependent inverse model for 64 partitions of the globe (TDI64) (Patra et al., 2005) to estimate monthly averaged carbon fluxes between the atmosphere and land/ocean. The Center for Climate System Research/National Institute for Environmental Studies/Frontier Research Center for Global Change (CCSR/NIES/FRCGC) AGCM transport is nudged with NCEP DOE/AMIP II re- analysis products for horizontal winds and temperature at 6hourly intervals (Numaguti et al., 1997; Kanamitsu et al., 2002; Patra et al., 2009a). ACTM horizontal resolution is set at T42 spectral truncations and the vertical grid contains 32 sigma-pressure layers between the earth's surface and $\sim 45 \mathrm{~km}$.

Regional $\mathrm{CO}_{2}$ fluxes are estimated by the inversion of atmospheric $\mathrm{CO}_{2}$ data using atmospheric 3-dimensional transport models (e.g., Rayner et al., 2008; Gurney et al., 2004). We use 3 prescribed fluxes in the inversion: (1) fossil fuel emission from the Emission Database for Global Atmospheric Research (EDGAR version 4, 2009) (EDGAR4, 2009), scaled to the Carbon Dioxide Information Analysis Center (CDIAC) global totals (Boden et al., 2010), (2) annually neutral terrestrial biosphere fluxes from the CarnegieAmes-Stanford Approach (CASA) ecosystem model (Randerson et al., 1997), and (3) sea-air oceanic exchange calculated using shipboard measurements of $\mathrm{CO}_{2}$ partial pressures (Takahashi et al., 2002). The EDGAR4 anthropogenic emissions are available until 2005 and are extrapolated linearly for the 2006-2008 period without accounting for varying regional trends. Thus, the South Asian fossil emissions as used in this study ( $0.45 \mathrm{Pg} \mathrm{Cyr}^{-1}$ for 2008) may have been slightly lower than actual. The CDIAC reports fossil fuel emissions of $0.48 \mathrm{Pg} \mathrm{Cyr}^{-1}$ for India alone in 2008 (increasing by $\sim 0.035 \mathrm{Pg} \mathrm{C} \mathrm{yr}^{-1}$ during 2006-2008), of $0.045 \mathrm{Pg} \mathrm{C} \mathrm{yr}^{-1}$ for Pakistan, and of $0.012 \mathrm{PgC} \mathrm{yr}^{-1}$ for Bangladesh. These values are higher than the estimations calculated within India for anthropogenic emission of $\mathrm{CO}_{2}$ for 2007, i.e., 0.33 $\mathrm{Pg} \mathrm{Cyr}^{-1}$ (INCCA, 2010). Use of lower fossil fuel emission in inversion would lead to an estimation of weaker terrestrial uptake by the terrestrial biosphere for maintaining the mass balance to fit the measured values by the forward model. The inverse model setup is close to that of TransCom-3 for deriving 22-region flux (TDI22) for 20002002 (Gurney et al., 2004), but in our case fluxes are estimated for 64 partitions of the globe (Patra et al., 2005) using ACTM's forward model transport.

We used ACTM also for forward simulations of the tracers $\mathrm{SF}_{6}, \mathrm{CO}_{2}, \mathrm{CH}_{4}$ and $\mathrm{N}_{2} \mathrm{O}$ to compare results with the CARIBIC and CONTRAIL measurements. $\mathrm{SF}_{6}, \mathrm{CH}_{4}$ and $\mathrm{N}_{2} \mathrm{O}$ are important as they can be used for separating the roles of surface fluxes, tropospheric transport and stratosphere-troposphere exchange in simulated tracer distributions. Annual mean emission distributions of $\mathrm{SF}_{6}$ (EDGAR4, 2009), scaled with global totals from Levin et al. (2010), are transported using ACTM (as in Patra et al., 2009a). For $\mathrm{CO}_{2}$ forward simulations, inversion fluxes (TDI22 and 3 sets of TDI64) and fossil fuel emission from EDGAR4 are used. The $\mathrm{CH}_{4}$ simulation uses the EDGAR3.2 anthropogenic emission distribution, scaled to EDGAR HYDE global totals (Olivier and Berdowski, 2001) and Goddard Institute of Space Studies (GISS) natural emission (Fung et al., 1991 and references therein). Because EDGAR3.2 provides $\mathrm{CH}_{4}$ emissions for different emission 
types separately, it is preferred over EDGAR4 because GISS emissions due to biomass burning or rice cultivation can be easily incorporated. The details of emission combinations and factors applied to each $\mathrm{CH}_{4}$ emission types are specified elsewhere (Patra et al., 2009b). $\mathrm{N}_{2} \mathrm{O}$ forward simulations are made using annual mean land fluxes (Bouwman et al., 1995) and monthly mean oceanic fluxes (Nevison et al., 1995), and stratospheric loss calculated using $\mathrm{N}_{2} \mathrm{O}$ reactions with $\mathrm{O}^{1} \mathrm{D}$ and photolysis (Sander et al., 2006). (Please see Ishijima et al., 2010 for further details on $\mathrm{N}_{2} \mathrm{O}$ simulation results using ACTM, but using 67 vertical layers and different combinations of $\mathrm{N}_{2} \mathrm{O}$ fluxes).

\subsection{Atmospheric observations}

We use three sets of atmospheric observations: (1) A preprocessed weekly-mean data product based on long-term and systematic measurements of $\mathrm{CO}_{2}$ from 92 sites around the globe (GLOBALVIEW-CO ${ }_{2}, 2009$ ). (2) Campaign based $\mathrm{CO}_{2}$ data between Frankfurt (FRA) and Chennai (MAA) during April-December 2008 on board the Lufthansa passenger aircraft at about $10 \mathrm{~km}$ altitude level by the CARIBIC project (Brenninkmeijer et al., 2007; Schuck et al., 2010). 28 samples were collected each month at regular latitudelongitude intervals except for July (27 samples). The total was 251 samples. The scheduled departure times for FRA to MAA and MAA to FRA are 09:00 UT and 20:15 UT, respectively, and air sampling starts when the aircraft reaches $450 \mathrm{mb}$ pressure altitude. For the January-March period the CARIBIC data could be extrapolated using model simulations because the ACTM forward simulation agreed well (mostly within $0.5 \mathrm{ppm}$ at all latitudes) for April 2008 with CARIBIC data and for January-March 2007 with CONTRAIL data (see Supplement Figs. 1 and 2). (3) Campaign based $\mathrm{CO}_{2}$ vertical distributions (profiles) measured over Delhi airport in 2007 using the Continuous $\mathrm{CO}_{2}$ Measuring Equipment (CME) on board a Japan Airlines (JAL) passenger aircraft by the CONTRAIL project (Machida et al., 2008; Matsueda et al., 2008). We note that the CARIBIC and CONTRAIL data are not simultaneous and that there is non-uniform data coverage for these 2 years. For the $\mathrm{CO}_{2}$ flux inversion (using CARIBIC) only 2008 was available. For cross-validating the inverted fluxes (using CONTRAIL) 2008 is incomplete and 2007 data was used. The $\mathrm{CO}_{2}$ measurements collected from various organizations worldwide are homogenized using the World Meteorological Organization (WMO) calibration scale (GLOBALVIEW- $\mathrm{CO}_{2}$; Masarie et al., 2001). The CARIBIC data are also reported on the WMO scale, using calibration gas mixtures from NOAA Earth System Research Laboratory (Schuck et al., 2009). Although the CONTRAIL data are reported on the NIES-95 scale (Machida et al., 2009), differences between the WMO and the NIES $\mathrm{CO}_{2}$ scales are less than $0.12 \mathrm{ppm}$. Thus different data sources fit well together, and are complementary to each other as seen from this study.

\section{Results and discussions}

We present here the first study to estimate $\mathrm{CO}_{2}$ fluxes from the South Asia region that is well constrained by observations, in particular for the South Asian summer monsoon season. Using recent atmospheric $\mathrm{CO}_{2}$ observations from the passenger aircraft projects CARIBIC and CONTRAIL we further apply forward transport simulations to estimate $\mathrm{CO}_{2}$ fluxes for 64 partitions of the globe, with an emphasis on the South Asia partition $\left(62-96^{\circ} \mathrm{E}, 0-34^{\circ} \mathrm{N}\right.$; land only; area: $5.26 \times 10^{6} \mathrm{~km}^{2}$ ).

Figure 1 shows the model-CARIBIC comparison for $\mathrm{CH}_{4}$, $\mathrm{N}_{2} \mathrm{O}, \mathrm{SF}_{6}$ and $\mathrm{CO}_{2}$. The time series of latitudinal $\mathrm{CH}_{4}, \mathrm{~N}_{2} \mathrm{O}$, $\mathrm{SF}_{6}$ and $\mathrm{CO}_{2}$ profiles are well captured with Pearson's moment correlation coefficients being $r=0.69,0.89,0.76$ and 0.77 (number of data points, $N=251$ ), respectively. Low concentrations observed (especially $\mathrm{CH}_{4}$ and $\mathrm{N}_{2} \mathrm{O}$ ) during winter and spring for flight sections in the lowermost stratosphere at northern mid-latitudes are captured by the model with accurate timing but sometimes with weaker amplitudes. Model's resolution, causing partly too young age of air in the stratosphere, is not sufficient to capture the low concentrations measured in the lowermost stratosphere properly. Of importance are however the prominent differences in $\mathrm{CO}_{2}$ for July-September when the simulated (ACTM) and the observed latitudinal profiles have opposing patterns. For this time period, both measured and simulated $\mathrm{CH}_{4}$ shows high values in the latitude range of $15-35^{\circ} \mathrm{N}$ indicating influence of surface sources. Due to strong upwelling through the Hadley upward branch of circulation in the presence of frequent widespread convective activities, $\mathrm{CH}_{4}$ (having emissions over land) is transported rapidly to the aircraft's cruise altitude. On the contrary, the $\mathrm{CO}_{2}$ observations document concomitantly strong carbon uptake at the surface. This uptake was estimated earlier solely using tracer-tracer correlations and existing emission inventories of $\mathrm{SF}_{6}$ (Schuck et al., 2010). In the following, we focus on advanced $\mathrm{CO}_{2}$ source and sink calculations using inverse modeling by ingesting the CARIBIC data, followed by validation of the obtained fluxes using the independent vertical profile measurements over Delhi airport from CONTRAIL. In this we lend confidence about realistic transport in the ACTM from the successful $\mathrm{CH}_{4}, \mathrm{~N}_{2} \mathrm{O}$ and $\mathrm{SF}_{6}$ simulations, and attribute the large $\mathrm{CO}_{2}$ discrepancies to erroneous surface fluxes for this gas. Noted is that forward transport simulation of multitracers, as opposed to adopting multi-models for $\mathrm{CO}_{2}$ only (Stephens et al., 2007), is a powerful method for model transport validation because the shape of simulated profiles depends strongly on the quality of implemented surface fluxes.

Figure 2 gives the spatial distribution of $\mathrm{CO}_{2}$ fluxes for two seasons for which the CARIBIC observations are expected to provide additional constraints. During the JJA season most land regions of the northern hemisphere act as a strong sink, except the South Asia region for the TDI64 inversion (Fig. 2a). This is contradictory to an expected 

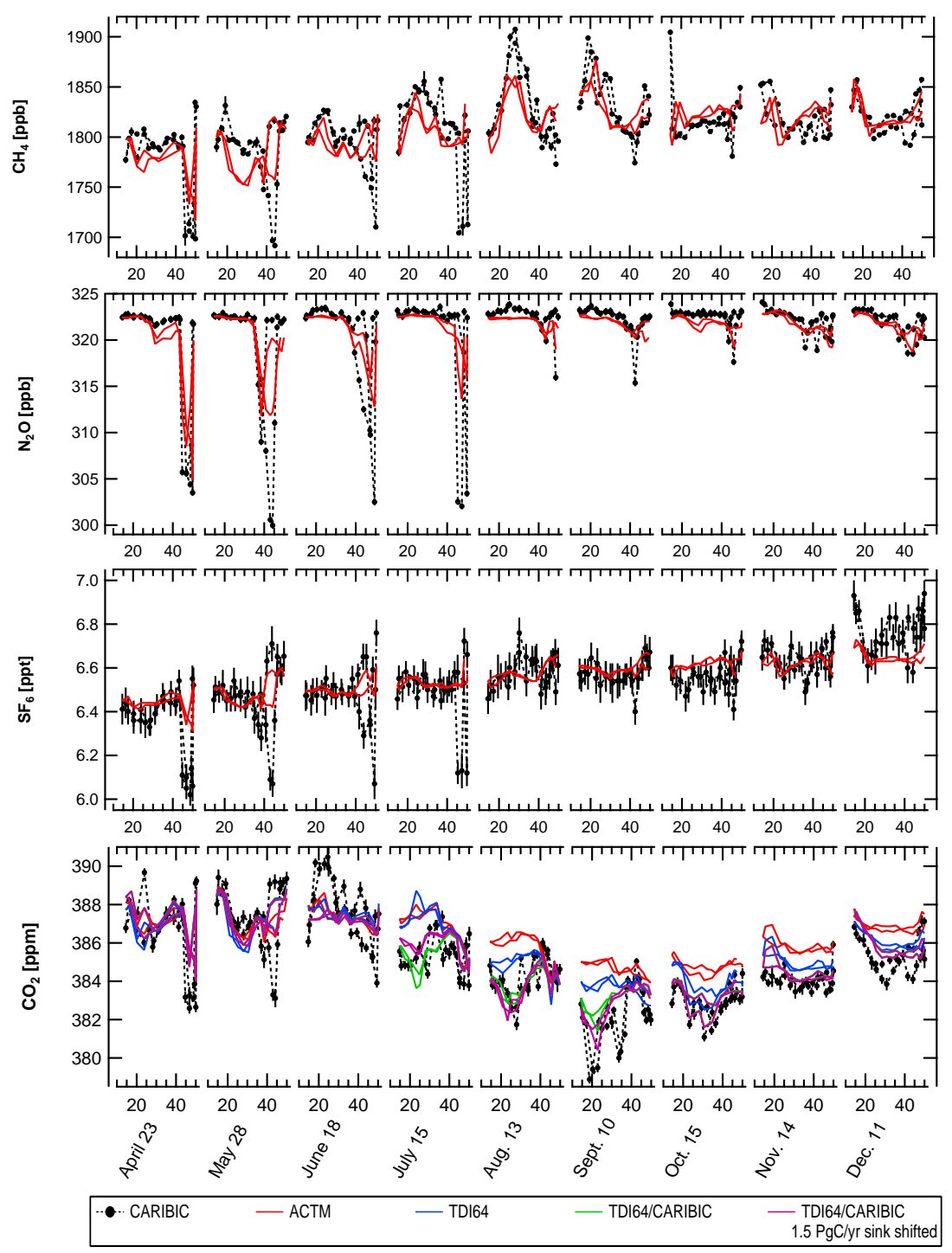

Fig. 1. Comparison between ACTM simulated concentrations and CARIBIC observations for $\mathrm{CH}_{4}, \mathrm{~N}_{2} \mathrm{O}, \mathrm{SF}_{6}$ and $\mathrm{CO}_{2}$ for $\mathrm{April}_{-}$ December 2008. The $\mathrm{x}$-axis is a time series of latitudinal profiles. Samples collected during outward bound flights (FRA-MAA) and return flights (MAA-FRA) are arranged by latitude for different months. Low $\mathrm{N}_{2} \mathrm{O}$ and $\mathrm{SF}_{6}$ indicate stratospheric air (stratospheric air being older has lower concentrations and $\mathrm{N}_{2} \mathrm{O}$ has a stratospheric sink). Low $\mathrm{CH}_{4}$ also indicates stratospheric air mainly due to chemical loss in absence of sources. $\mathrm{SF}_{6}$ and $\mathrm{CH}_{4}$ are very useful for validating convective transport in ACTM as they both have basically only continental surface sources. Four cases of $\mathrm{CO}_{2}$ simulations are produced by combining fossil fuel emission distribution and inverse model fluxes from TDI22 (ACTM) or 3 cases of TDI64 (as discussed later).

intense carbon uptake under the influence of the South Asian monsoon rainfall. This scenario however changes when CARIBIC $\mathrm{CO}_{2}$ observations are used in the inversion (Fig. 2c). For the SON season, both inversions produced similar $\mathrm{CO}_{2}$ fluxes, suggesting the information content in the CARIBIC data are in agreement with that in GLOBALVIEW- $\mathrm{CO}_{2}$. Figure 3 shows the full seasonal cycle of $\mathrm{CO}_{2}$ fluxes for three Asian and Arabia regions of the 64-region inverse model, and temperature and rainfall variations for the South Asia region. We find significant flux differences between the inversions using GLOBALVIEW$\mathrm{CO}_{2}$ only (referred as TDI64) and GLOBALVIEW-CO $\mathrm{CO}_{2}$ plus CARIBIC (TDI64/CARIBIC) data for South Asia for July and September. Note that the changes in South Asia flux do not disturb the fluxes from the neighbouring regions of Northwest Asia and Arabia (Fig. 3a-b), even though the CARIBIC flight tracks pass over these regions. Moreover the a posteriori flux uncertainty of South Asia region for July strongly reduced from 1.5 to $0.68 \mathrm{Pg} \mathrm{C} \mathrm{yr}^{-1}$ (Fig. 3d). These uncertainty reductions are limited mainly to the summer 


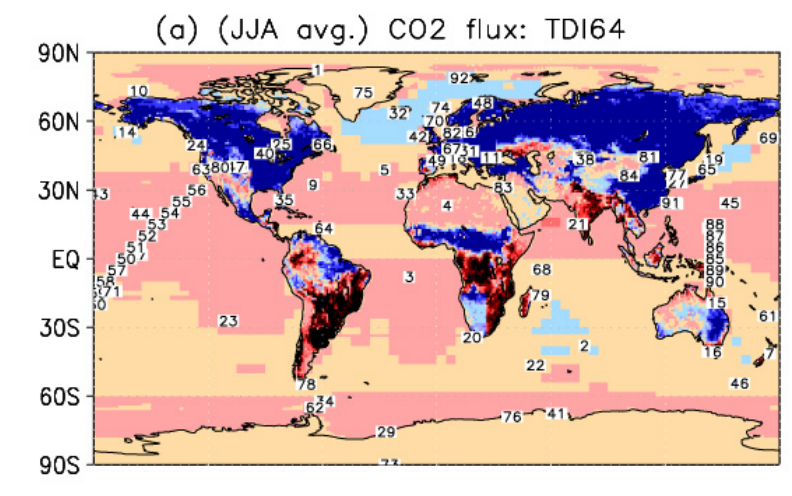

(c) TDI64/CARIBIC - TDI64 (mg-C/m2/day)
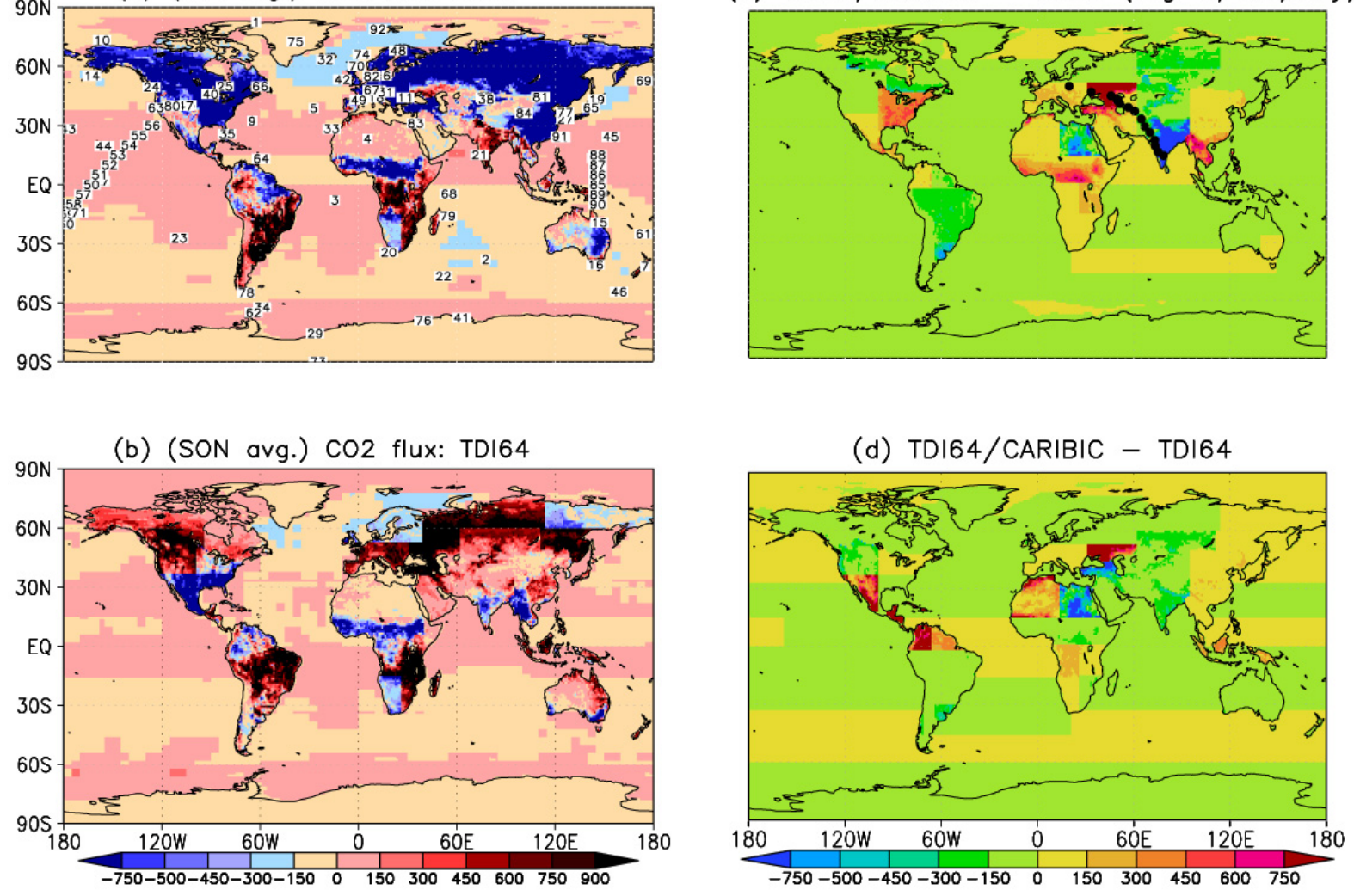

Fig. 2. Three-monthly mean flux distribution maps for June-July-August (JJA; top row) and September-October-November (SON; bottom row) 2008, prepared by distributing 64 region fluxes on to $1 \times 1^{\circ}$ latitude-longitude grids for TDI64 inversion using GLOBALVIEW-CO 2 and ACTM forward transport (left column; (a) and (b), respectively). The right column panels (c and d) show differences in estimated fluxes by including CARIBIC data additionally in inversion (TDI64/CARIBIC). The observation sites used in TDI64 and TDI64/CARIBIC inversions are shown as numbers in panels (a) and (c), respectively. Note that the CARIBIC observation locations between FRA and MAA are shown as average flight tracks in panel (c) (marked by filled circles for 14 locations as used in inversion).

months, which are otherwise among the largest for four Asian regions. This shows that upper tropospheric data are useful for flux inversion studies when vertical transport is efficient. To constrain inversion fluxes all year round, additional vertical profile or surface measurements are required. We note, as stated earlier, that the CARIBIC observations did not cover January-March 2008, and that the inversion is performed with one single year's data. The TDI64/CARIBIC inversion for the South Asia region results in an annual net sink of $0.37 \pm 0.20 \mathrm{Pg} \mathrm{C} \mathrm{yr}^{-1}$ for 2008 (Fig. 2c), which was otherwise assigned a net source of

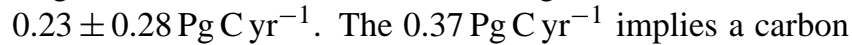
sink density of $62.5 \mathrm{~g} \mathrm{C} \mathrm{m}^{-2} \mathrm{yr}^{-1}$. This value exceeds the $\sim 25,20$, or $47 \mathrm{~g} \mathrm{C} \mathrm{m}^{-2} \mathrm{yr}^{-1}$ estimated for China, Europe or United States (Piao et al., 2009), and may be a characteristic of tropical land biosphere having stronger gross primary productivity (Beer et al., 2010). The magnitude of such a considerable net flux (with reduced uncertainty) has very important implications for the carbon budget calculations of the South Asian region as it has a net source of $0.45 \mathrm{Pg} \mathrm{C} \mathrm{yr}^{-1}$ from fos- sil fuel burning (as used in the forward and inverse models). The Ministry of Environment and Forests, Government of India estimates that India's forest and crop lands acted as a net sink of carbon by $0.074 \mathrm{Pg} \mathrm{Cyr}^{-1}$ in 2007 (INCCA, 2010). While this is only about $20 \%$ of the inversion estimate, we believe other countries within the inverse model region also play a significant part in carbon sequestration of this region.

The South Asian ecosystem has a tendency to become a moderate source of carbon (average release rate of $0.65 \mathrm{Pg} \mathrm{C} \mathrm{yr}^{-1}$ ) during April-May, from a weak sink in December-January (Fig. 3d), because of the prolonged dry season (Fig. 3e) combined with a rapid rise in air temperatures (Fig. 3f). From June onwards a sharp increase in uptake occurs, with the maximum uptake rate of $2.83 \pm 0.69 \mathrm{Pg} \mathrm{C} \mathrm{yr}^{-1}$ in July, closely following the arrival of monsoonal rainfall. However, the subsequent weakening to $0.60 \pm 0.89$ can be considered specific to 2008 (as discussed later), as in general July and August are not water stressed due to ample rainfall (Fig. 3e). The ecosystem model CASA produces a much weaker seasonal cycle, which 

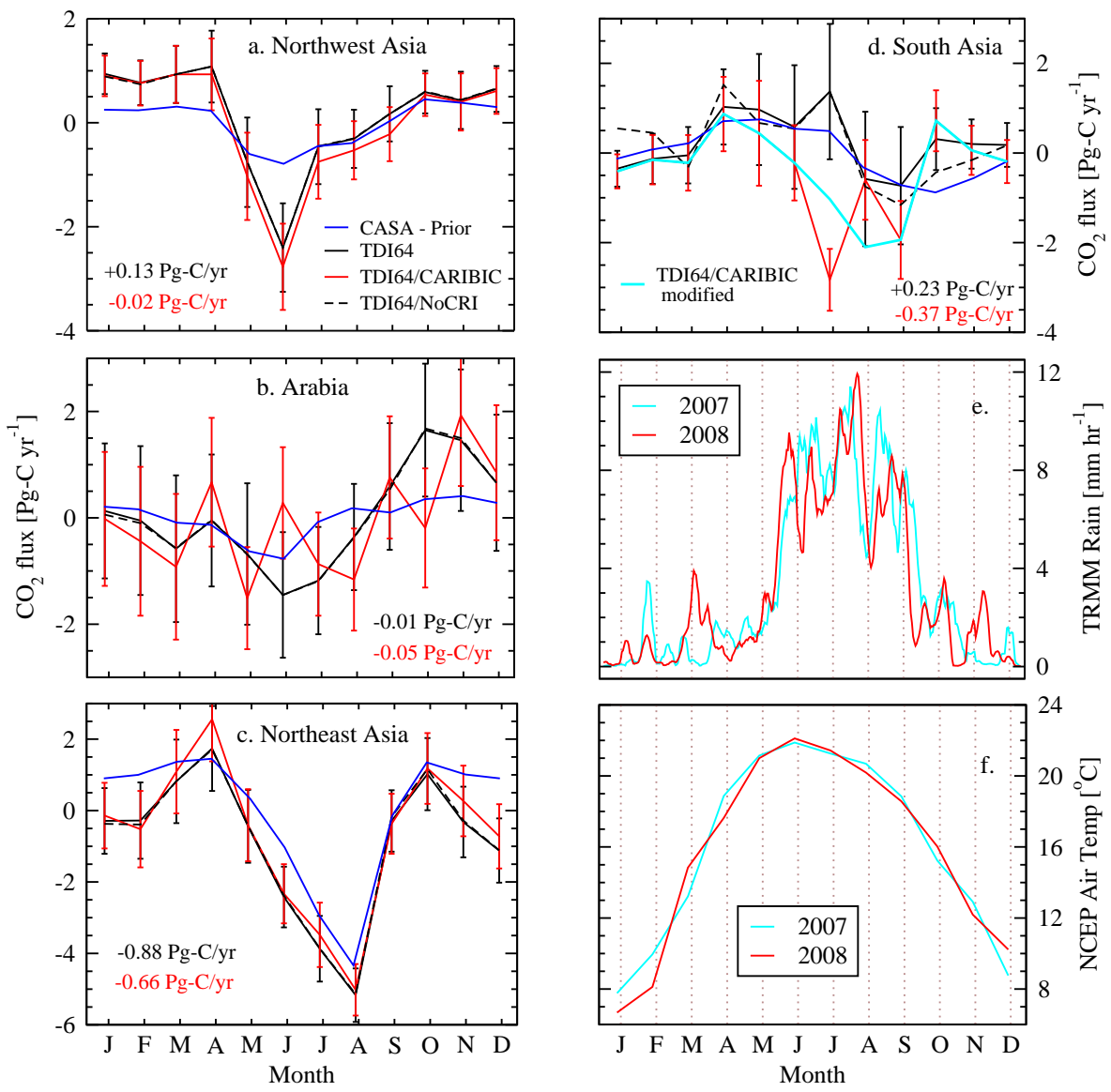

Fig. 3. Comparisons of $\mathrm{CO}_{2}$ flux seasonal cycles of 4 Asian regions in 64-region inversion (a-d) for 2008. The numbers within each panel are annual total $\mathrm{CO}_{2}$ fluxes ( $>0$ for sources or net release by the land biosphere; $<0$ for sinks or net uptake) only for TDI64 and TDI64/CARIBIC inversion cases. A sensitivity inversion run without including the Cape Rama, India site (TDI64/NoCRI) is also shown for comparison. This figure reveals maximum impact of CARIBIC data on South Asian flux prediction by 64-region inverse model, in particular during the JAS months (ref. Fig. 2 for global distribution). We also show (e) Tropical Rainfall Measuring Mission (TRMM) daily rainfall data at daily time intervals (Iguchi et al., 2000; data source: http://mirador.gsfc.nasa.gov), and (f) the air temperature at $2 \mathrm{~m}$ from the National Center for Environmental Prediction (NCEP) reanalysis (source: www.cdc.noaa.gov) for 2007 and 2008. Tickmarks are shown at middle of month.

is in agreement with the TDI64 simulation but not with the TDI64/CARIBIC result (cf. Fig. 3d). The underestimation of the seasonal cycle up to about $50 \%$ by the ecosystem model may arise from missing representations of agricultural waste and biomass burning for the spring-time carbon release, and most importantly proper crop phenology (Lokupitiya et al., 2009) for the summer-time uptake. Apparently, gross carbon uptake in South Asia is closely coupled with temperature and precipitation, in contrast to the temperate and boreal regions, where temperature effects dominate. We note in this respect that even the most recent estimations of gross carbon uptake could not be validated using local/regional measurements (Beer et al., 2010). Our ignorance of the seasonal variation of $\mathrm{CO}_{2}$ fluxes may impede further development of terrestrial ecosystem models.
There appears to be no direct way to verify our inversion model results using field measurements of actual carbon fluxes, whereas the ecosystem model offers little help either. Instead we use an independent set of vertical profiles measurements in the central part of South Asia by CONTRAIL in 2007 during ascent and descent at Delhi airport. Since the observations by CARIBIC and CONTRAIL are available for different years, and $\mathrm{CO}_{2}$ fluxes have significant inter-annual variability, the model simulations cannot be compared directly. Figure 4 shows the individual vertical profiles for 11 months in 2007 (no data for May), and the monthly averaged model simulations. The model results are sampled on the day and hour of observation over Delhi $\left(28.57^{\circ} \mathrm{N}, 77.10^{\circ} \mathrm{E}\right)$. Interestingly, all monthly vertical $\mathrm{CO}_{2}$ profiles are distinct and the model profiles capture several observed features successfully. The model-observation agreement depends greatly on 

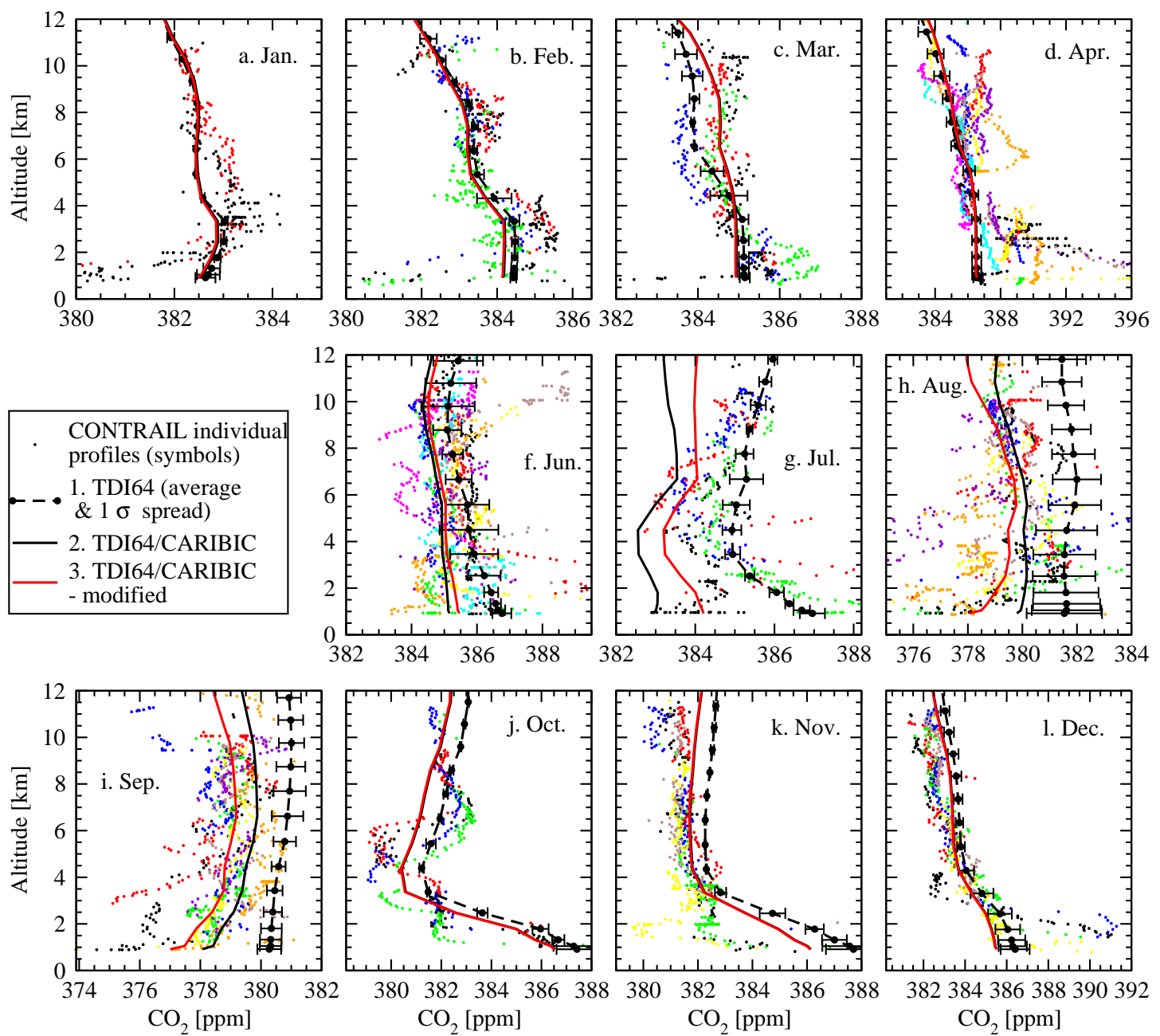

Fig. 4. Validation of TDI predicted surface fluxes by comparing the ACTM simulated $\mathrm{CO}_{2}$ concentrations with CONTRAIL measurements of vertical profiles over Delhi. While individual CONTRAIL profiles are shown within each panel for a month, the ACTM profiles are shown as average values (and $1 \sigma$ spread for TDI64 case only) corresponding to 3 inversion fluxes (legend \#1-3) at model vertical resolution. All the model results are adjusted to $382.5 \mathrm{ppm}$ at $8 \mathrm{~km}$ altitude for the month of January, and variable x-axis range is adopted to reveal maximum information content in each monthly set of profiles. Comparison of seasonal or 3-monthly mean profiles is shown in Fig. 5, exhibiting model simulations using TDI64/CARIBIC fluxes agree within $1 \mathrm{ppm}$ at all heights in most seasons. The solid black line is visible separately from the solid red line only for June-September.

the surface fluxes incorporated in ACTM. For example, improvements are discernable for August-November when the TDI64/CARIBIC derived fluxes are used for the profile shape as well as for the average concentrations in comparison with those using TDI64 predicted fluxes (dashed/broken line with error bars, representing $1 \sigma$ spread in the model profiles).

Apparently, the model-CONTRAIL observation agreement worsens specifically for July when TDI64/CARIBIC fluxes are used. To explain this we consider that the interannual variability in the summer monsoon rainfall is large; e.g., in $200828 \%$ excess in June and 5\% in July, compared to $18 \%$ and $8 \%$, respectively for 2007 were observed over India (all relative to climatological mean monthly rainfall for the period 1979-2008) (Parthasarathy et al., 1994, updated values on Monsoon Online at www.tropmet.res.in; see also Fig. 3e for South Asian rainfall as observed by the TRMM satellite). Assuming a one-month delay in ecosystem response, the large amount of rainfall in June 2008 would have resulted in enhanced carbon uptake as derived from TDI64/CARIBIC. This might not have been the case in 2007. For a sensitivity analysis we therefore shifted a sink of $1.5 \mathrm{Pg} \mathrm{C} \mathrm{yr}^{-1}$ sink from July to August and repeated the ACTM simulation for 2007 (Fig. 3d, cyan line). This resulted in a better agreement with CONTRAIL for all months. Thus, the total summer time uptake in South Asia is much less variable than the monthly mean fluxes in interannual time scales and is relatively well conserved between 2007 and 2008 . 
Table 1. Statistics ( $r$ and NSD) showing overall performance of ACTM simulations in comparison with CONTRAIL measurements at upper tropospheric altitudes (300-200 mb) around 6 airport sites (ref. Fig. 6a-f). The $r$ values greater than 0.45 are statistically significant at $99 \%$ confidence interval in student's-T two-tailed test for 30 data points. Although $r$ did not increase for TDI64/CARIBIC compared to TDI64, the NSDs improved for NRT, BKK and MNL. No overall difference is noted for KUL and CGK where results appeared best for TDI64. The

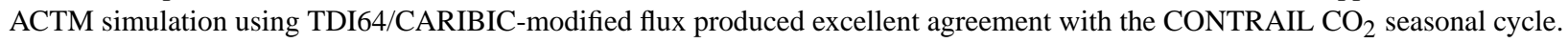

\begin{tabular}{|c|c|c|c|c|c|c|c|c|c|}
\hline \multirow{2}{*}{$\begin{array}{l}\text { Airport } \\
\text { code }\end{array}$} & \multicolumn{4}{|c|}{ Correlation coefficient $(r)$} & \multirow{2}{*}{$\begin{array}{r}\text { No. of } \\
\text { data } \\
\text { points } \\
(N)\end{array}$} & \multicolumn{4}{|c|}{ Normalized standard deviation (NSD) } \\
\hline & ACTM & TDI64 & $\begin{array}{r}\text { TDI64/ } \\
\text { CARIBIC }\end{array}$ & $\begin{array}{r}\text { TDI64/ } \\
\text { CARIBIC } \\
\text { modified }\end{array}$ & & ACTM & TDI64 & $\begin{array}{r}\text { TDI64/ } \\
\text { CARIBIC }\end{array}$ & $\begin{array}{r}\text { TDI64/ } \\
\text { CARIBIC } \\
\text { modified }\end{array}$ \\
\hline NRT & 0.75 & 0.70 & 0.72 & 0.72 & 174 & 0.72 & 0.77 & 0.84 & 0.85 \\
\hline DEL & 0.73 & 0.89 & 0.91 & 0.92 & 33 & 0.47 & 0.63 & 0.80 & 0.96 \\
\hline BKK & 0.54 & 0.75 & 0.75 & 0.75 & 42 & 0.64 & 0.56 & 0.68 & 0.70 \\
\hline KUL & 0.24 & 0.57 & 0.54 & 0.53 & 32 & 1.30 & 0.94 & 0.93 & 0.94 \\
\hline CGK & 0.46 & 0.57 & 0.51 & 0.51 & 55 & 1.35 & 1.08 & 1.15 & 1.15 \\
\hline MNL & 0.89 & 0.93 & 0.93 & 0.93 & 81 & 0.80 & 0.86 & 0.90 & 0.91 \\
\hline
\end{tabular}
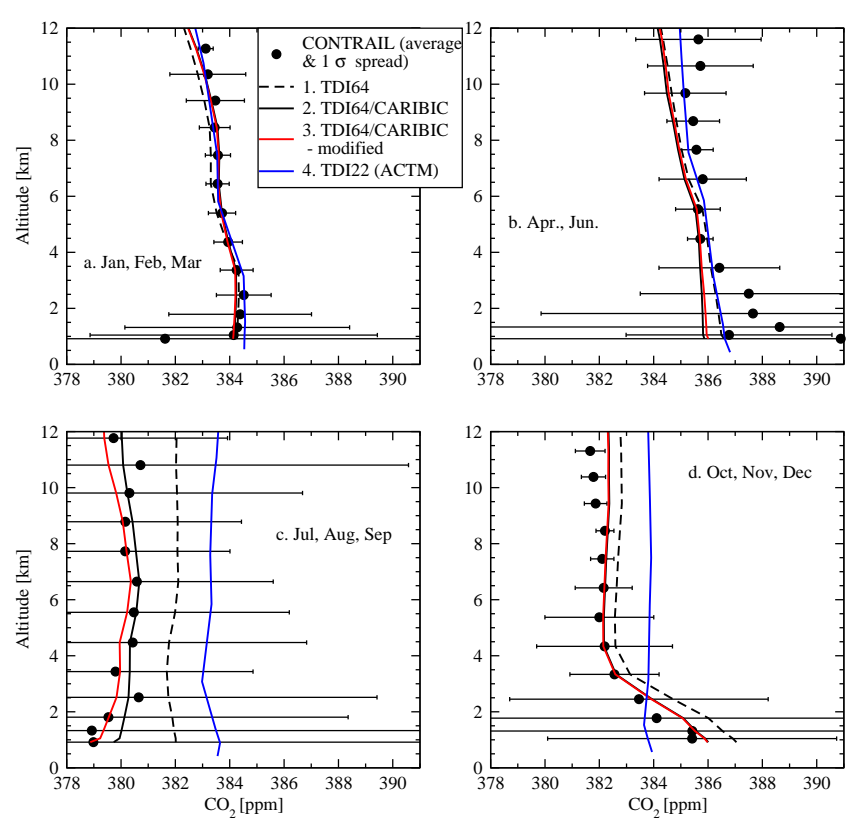

Fig. 5. Similar to Fig. 4, but seasonal mean $\mathrm{CO}_{2}$ profiles are shown as the ACTM simulations at T42 horizontal resolution are not likely to capture individual CONTRAIL profiles over Delhi. Additionally, ACTM simulated vertical profiles using TDI22 inversion flux are shown here. $\mathrm{CO}_{2}$ seasonal cycles at different height levels over Delhi are shown in Supplement Fig. 2.

The model-observation comparisons using seasonally averaged profiles exhibit a much simpler picture (Fig. 5), and confirm that an annual uptake of approximately $0.37 \mathrm{PgC} \mathrm{yr}^{-1}$ in the South Asia region is required for the ACTM to properly simulate the seasonal cycle's amplitude and vertical profile gradients measured by $\mathrm{CON}$ TRAIL. In contrast, a $0.23 \mathrm{Pg} \mathrm{Cyr}^{-1}$ source (TDI64 case) produces a significant bias of at least 2 ppm in summer (JulySeptember), rendering such an ecosystem based $\mathrm{CO}_{2}$ release from this region unlikely. We add to this that the correlations between CARIBIC observations and the ACTM model results improve from $r=0.77$ corresponding to TDI22 flux to $r=0.82$ and 0.87 when TDI64 and TDI64/CARIBIC fluxes are used (Fig. 1). Based on the close agreement in shape and concentration between the ACTM and CONTRAIL $\mathrm{CO}_{2}$ profiles for the January-March, July-September and OctoberDecember seasons, and a $\sim 1.5 \mathrm{ppm}$ offset below $3 \mathrm{~km}$ for April-June, we infer that the $0.37 \mathrm{Pg} \mathrm{C} \mathrm{yr}^{-1}$ uptake is slightly over-estimated for the year 2007.

It may be argued that the TDI64/CARIBIC inverse model estimation is biased towards a stronger carbon uptake due to sparse sampling of the air above the South Asia region by CARIBIC, yet some uncertainties in forward model transport and errors in the site representation due to coarse model horizontal resolution remained. As shown in Figs. 2 and 3, the $\mathrm{CO}_{2}$ flux changed significantly only for the South Asia region, little affecting the neighbouring regions' fluxes of Southeast Asia or remote regions in Africa or South/North America. Thus it is important to check whether these flux changes outside the South Asia region are deteriorating the greater Asian $\mathrm{CO}_{2}$ flux balance due to the use of CARIBIC data in the 64-region inverse model. Figure 6 shows comparison of $\mathrm{CO}_{2}$ seasonal cycles in the upper troposphere (cruise altitude) as measured by CONTRAIL over six locations in Japan, India and Southeast Asia. The Pearson moment correlation coefficients $(r)$ and normalized standard deviations (NSDs) are given in Table 1 as the measures of modelmeasurement agreements for the comparisons over these six Asian airports. NSD are used to compare the seasonal cycle amplitudes, and are calculated by normalizing the model standard deviation (SD) with the observed SD of the time series. Barring occasional low values in $\mathrm{CO}_{2}$ concentrations 


\section{Observed \\ TDI22 (or ACTM) \\ TDI64 \\ TDI64/CARIBIC \\ TDI64/CARIBIC modified}

SEASONALITY
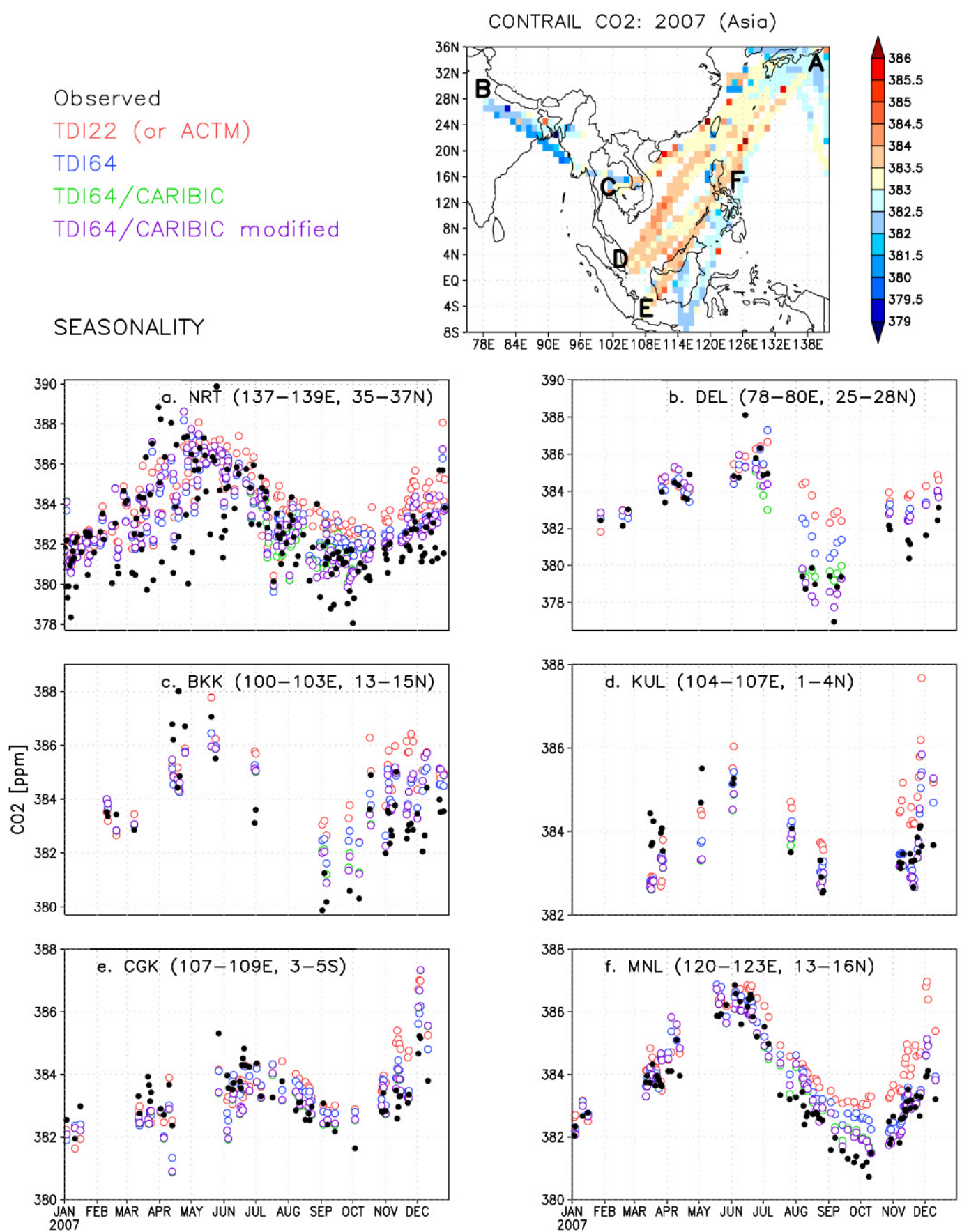

Fig. 6. Annual mean $\mathrm{CO}_{2}$ horizontal gradient between Japan and India as measured by CONTRAIL at aircraft cruise altitudes (top panel). Average $\mathrm{CO}_{2}$ seasonal cycles in the upper troposphere are shown in lower six panels around 6 airport sites; (a) Narita, Japan (NRT), (b) Delhi, India (DEL), (c) Bangkok, Thailand (BKK), (d) Kuala Lumpur, Malaysia (KUL), (e) Jakarta, Indonesia (CGK), and (f) Manila, Philippines (MNL). These locations are marked roughly in the top panel for reference by alphabet (a-f).

over KUL in early May and CGK in mid-April, we find the ACTM forward simulations using TDI64/CARIBIC fluxes produce better or comparable agreement at all locations. Remarkable agreement is obtained for both $r(\sim 0.91)$ and NSD over Delhi (0.97), when TDI64/CARIBIC-modified flux is used. It may be reminded here that Delhi is located about $30^{\circ} \mathrm{E}$ of the CARIBIC flight tracks. The $r$ and NSD statistics also improved over MNL, but remained unchanged over BKK. Note that the data coverage at MNL airport is denser than at BKK. 
(a) OLR (shaded) \& Wind vector at $200 \mathrm{mb}$ : JJA

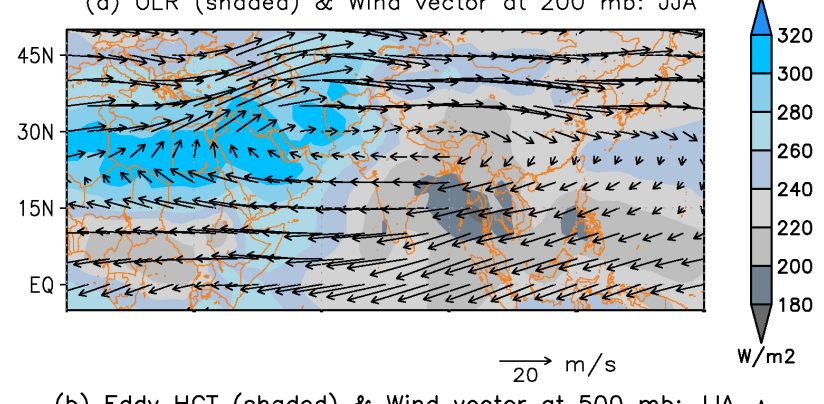

(b) Eddy HGT (shaded) \& Wind vector at $500 \mathrm{mb}$ : JJA

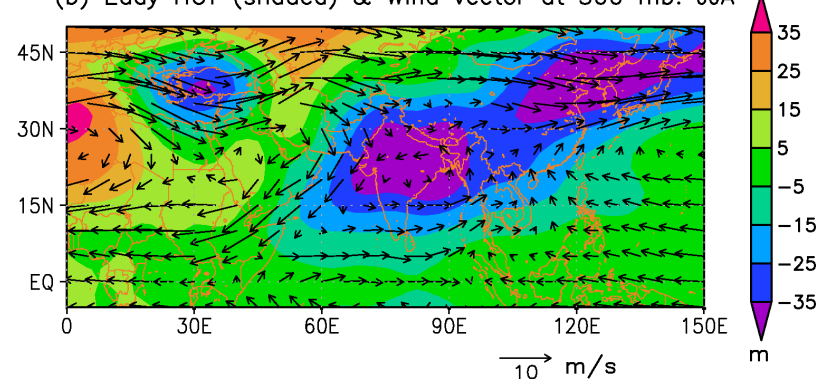

Fig. 7. Depiction of average meteorological parameters salient to the South Asian summer monsoon season (June-July-August); (a) NCEP outgoing longwave radiation (OLR) and wind vectors at $200 \mathrm{mb}$ height, (b) Eddy geopotential height (zonal mean subtracted) and wind vectors at $500 \mathrm{mb}$ height (data source: www.cdc. noaa.gov). The length of the wind vectors indicates wind speed as shown by the legends, separately for each panels. The response functions corresponding to $1 \mathrm{PgC} \mathrm{yr}^{-1}$ pulse emission from the South Asia region of TDI64 for February, May, August and November at selected upper tropospheric locations are shown in Supplement Fig. 3.

\section{Conclusions}

The TDI64 time-dependent inverse model was employed to estimate $\mathrm{CO}_{2}$ fluxes using ACTM forward transport simulations and CARIBIC data plus GLOBALVIEW- $\mathrm{CO}_{2}$ for the year 2008. Our main focus was on the South Asian region of the inverse model, where the CARIBIC data in the upper troposphere are likely to provide additional constraints on surface flux estimation. We found a net $\mathrm{CO}_{2}$ uptake of $0.37 \pm 0.20 \mathrm{Pg} \mathrm{C} \mathrm{yr}^{-1}$ by the South Asia region during 2008, which is also valid for 2007. Most part of this sink occurred in the Southwest monsoon season during July-September, while the other three seasons acted as weak sinks to a moderate source of $\mathrm{CO}_{2}$. The mean fluxes for the summer months differ largely from the presubscribed terrestrial flux as used in the inverse model (based on the CASA ecosystem model). We validated these monthly mean fluxes using independent measurement of the CONTRAIL project for vertical profiles over Delhi airport and seasonal cycles in the upper troposphere region over 6 airport locations between Delhi and Narita. We cannot attribute the cause of such a strong South Asian carbon uptake density $\left(62.5 \mathrm{~g} \mathrm{C} \mathrm{m}^{-2} \mathrm{yr}^{-1}\right)$, compared to the better studied temperate regions of China, Europe or North America, to a specific process. However, a recent study suggest that secondary forest (regrowth) and enhanced nitrogen deposition in the South Asian region may have accelerated in recent years (Yang et al., 2010) and thus our estimations are in fair agreement with their ecosystem model results for the 1990s $\left(\sim 50.0 \mathrm{~g} \mathrm{C} \mathrm{m}^{-2} \mathrm{yr}^{-1}\right)$.

Our analysis shows that the horizontal cross-sections in the upper troposphere can be extremely useful for constraining regional carbon budgets, provided the forward transport models adequately represent the region-specific dynamical structures. Figure 7 shows the meteorological conditions that allowed the measurements by CARIBIC and CONTRAIL in the upper troposphere to strongly constrain South Asian $\mathrm{CO}_{2}$ uptake during the summer season. In the upper troposphere region (Fig. 7a), where the CONTRAIL and CARIBIC measurements took place, a strong anticyclonic circulation confines the air mass with surface fluxes signal over South Asia. The eddy geopotential height distribution suggests a strong low-pressure system prevailed over the South Asian region (seen as negative Eddy HGT and low OLR) and the wind vectors show that the air mass is also isolated within the region from mixing with surrounding region up to the middle troposphere (Fig. 7b). In contrast, strong winds prevailed over other low-pressure regions in the East Asia and Europe in the mid-upper troposphere. CONTRAIL measurements over the Western Pacific Ocean (Matsueda et al., 2002) have also been found to capture strong surface flux signals, such as that from intense fires in Southeast Asia, which are otherwise not recorded by the existing surface observation network (Patra et al., 2005).

\section{Supplementary material related to this article is available online at: http://www.atmos-chem-phys.net/11/4163/2011/ acp-11-4163-2011-supplement.pdf.}

Acknowledgements. This work is partly supported by JSPS/MEXT KAKENHI-A grant number 22241008. CARIBIC acknowledges support of the European Commission through the GEOmon (Global Earth Observation and Monitoring) Integrated Project under the 6th Framework Program (contract number FP6-2005-Global-4036677). The CARIBIC flying observatory is enabled by Lufthansa and sponsored by Frankfurt Airport. CONTRAIL is supported by the JAL foundation, Ministry of Education, Culture, Sports, Science and Technology (MEXT), and Ministry of Environment (MOE), Japan. We thank Sumana Bhattacharya, Rachel Law and Pieter Tans for insightful discussions and providing feedback on an early manuscript draft.

Edited by: C. Gerbig 


\section{References}

Assonov, S. S., Brenninkmeijer, C. A. M., Schuck, T. J., and Taylor, P.: Analysis of ${ }^{13} \mathrm{C}$ and ${ }^{18} \mathrm{O}$ isotope data of $\mathrm{CO}_{2}$ in CARIBIC aircraft samples as tracers of upper troposphere/lower stratosphere mixing and the global carbon cycle, Atmos. Chem. Phys., 10, 8575-8599, doi:10.5194/acp-10-8575-2010, 2010.

Bhattacharya, S. K., Borole, D. V., Francey, R. J., Allison, C. E., Steele, L. P., Krummel, P., Langenfelds, R., Masarie, K. A., Tiwari, Y. K., and Patra, P. K.: Trace gases and $\mathrm{CO}_{2}$ isotope records from Cabo de Rama, India, Curr. Sci., 97, 1336-1344, 2009.

Beer, C., Reichstein, M., Tomelleri, E., Ciais, P., Jung, M., Carvalhais, N., Rödenbeck, C., Arain, M. A., Baldocchi, D., Bonan, G. B., Bondeau, A., Cescatti, A., Lasslop, G., Lindroth, A., Lomas, M., Luyssaert, S., Margolis, H., Oleson, K. W., Roupsard, O., Veenendaal, E., Viovy, N., Williams, C., Woodward, F. I., and Papale, D.: Terrestrial gross carbon dioxide uptake: global distribution and covariation with climate, Science, 329, 834-838, 2010.

Boden, T. A., Marland, G., and Andres, R. J.: Global $\mathrm{CO}_{2}$ Emissions from Fossil-Fuel Burning, Cement Manufacture, and Gas Flaring: 1751-2006, Carbon Dioxide Inf. Anal. Cent., Oak Ridge Natl. Lab., Oak Ridge, Tenn., 2010.

Bouwman, A. F., van der Hoek, K. W., and Olivier, J. G. J.: Uncertainties in the global source distribution of nitrous oxide, J. Geophys. Res., 100(D2), 2785-2800, 1995.

Brenninkmeijer, C. A. M., Crutzen, P., Boumard, F., Dauer, T., Dix, B., Ebinghaus, R., Filippi, D., Fischer, H., Franke, H., Frieß, U., Heintzenberg, J., Helleis, F., Hermann, M., Kock, H. H., Koeppel, C., Lelieveld, J., Leuenberger, M., Martinsson, B. G., Miemczyk, S., Moret, H. P., Nguyen, H. N., Nyfeler, P., Oram, D., O’Sullivan, D., Penkett, S., Platt, U., Pupek, M., Ramonet, M., Randa, B., Reichelt, M., Rhee, T. S., Rohwer, J., Rosenfeld, K., Scharffe, D., Schlager, H., Schumann, U., Slemr, F., Sprung, D., Stock, P., Thaler, R., Valentino, F., van Velthoven, P., Waibel, A., Wandel, A., Waschitschek, K., Wiedensohler, A., Xueref-Remy, I., Zahn, A., Zech, U., and Ziereis, H.: Civil Aircraft for the regular investigation of the atmosphere based on an instrumented container: The new CARIBIC system, Atmos. Chem. Phys., 7, 4953-4976, doi:10.5194/acp-7-4953-2007, 2007.

Castaldi, S., de Grandcourt, A., Rasile, A., Skiba, U., and Valentini, R.: $\mathrm{CO}_{2}, \mathrm{CH}_{4}$ and $\mathrm{N}_{2} \mathrm{O}$ fluxes from soil of a burned grassland in Central Africa, Biogeosciences, 7, 3459-3471, doi:10.5194/bg-7-3459-2010, 2010.

EDGAR4: Emission Database for Global Atmospheric Research (EDGAR), release version 4.0, European Commission, Joint Research Centre (JRC)/Netherlands Environmental Assessment Agency (PBL), available at: http://edgar.jrc.ec.europa.eu (last access: 23 June 2009), 2009.

Fung, I., John, J., Lerner, J., Matthews, E., Prather, M., Steele, L. P., and Fraser, P. J.: Three- dimensional model synthesis of the global methane cycle, J. Geophys. Res., 96, 13033-13065, 1991.

GLOBALVIEW- $\mathrm{CO}_{2}$ : Cooperative Atmospheric Data Integration Project - Carbon Dioxide, CD-ROM, NOAA CMDL, Boulder, Colorado, anonymous FTP to ftp.cmdl.noaa.gov, path: ccq/CO2/GLOBALVIEW (last access: 30 October 2009), 2009.

Gurney, K. R., Law, R. M., Denning, A. S., Rayner, P. J., Pak, B. C., Baker, D., Bousquet, P., Bruhwiler, L., Chen, Y.-H., Ciais, P., Fung, I. Y., Heimann, M., John, J., Maki, T., Maksyutov., S.,
Peylin, P., Prather, M., and Taguchi, S.: Transcom 3 inversion intercomparison: model mean results for the estimation of seasonal carbon sources and sinks, Global Biogeochem. Cy., 18, GB1010, doi:10.1029/2003GB002111, 2004.

Iguchi, T., Kozu, T., Meneghini, R., Awaka, J., and Okamoto, K.: Rain-profiling algorithm for the TRMM precipitation radar, J. Appl. Meteorol., 39, 2038-2052, 2000.

INCCA, Indian Network for Climate Change Assessment, India: Greenhouse Gas Emissions 2007, Ministry of Environment and Forests, Government of India, New Delhi, May, 2010.

Ishijima, K., Patra, P. K., Takigawa, M., Machida, T., Matsueda, H., Sawa, Y., Steele, L. P., Krummel, P. B., Langenfelds, R. L., Aoki, S., and Nakazawa, T.: Stratospheric influence on the seasonal cycle of nitrous oxide in the troposphere as deduced from aircraft observations and model simulations, J. Geophys. Res., 115, D20308, doi:10.1029/2009JD013322, 2010.

Janssens, I. A., Freibauer, A., Ciais, P., Smith, P., Nabuurs, G., Schlamadinger, B., Hutjes, R., Schulze, E., Ceulemans, E., Valentini, R., and Dolman, J.: Europe's terrestrial biosphere absorbs 7 to $12 \%$ of European anthropogenic $\mathrm{CO}_{2}$ emissions, Science, 300, 1538-1542, 2003.

Kanamitsu, M., Ebisuzaki, W., Woollen, J., Yang, S.-K., Hnilo, J. J., Fiorino, M., and Potter, G. L.: NCEP-DOE AMIP-II reanalysis (R-2), B. Am. Meteorol. Soc., 83, 1631-1643, 2002.

Le Quéré, C., Raupach, M. R., Canadell, J. G., Marland, G., Bopp, L., Ciais, P., Conway, T. J., Doney, S. C., Feely, R. A., Foster, P., Friedlingstein, P., Gurney, K., Houghton, R. A., House, J. I., Huntingford, C., Levy, P. E., Lomas, M. R., Majkut, J., Metzl, N., Ometto, J. P., Peters, G. P., Prentice, I. C., Randerson, J. T., Running, S. W., Sarmiento, J. L., Schuster, U., Sitch, S., Takahashi, T., Viovy, N., van der Werf, G. R., and Woodward, F. I.: Trends in the sources and sinks of carbon dioxide, Nat. Geosci., 2, 831-836, 2009.

Levin, I., Naegler, T., Heinz, R., Osusko, D., Cuevas, E., Engel, A., Ilmberger, J., Langenfelds, R. L., Neininger, B., Rohden, C. v., Steele, L. P., Weller, R., Worthy, D. E., and Zimov, S. A.: The global $\mathrm{SF}_{6}$ source inferred from long-term high precision atmospheric measurements and its comparison with emission inventories, Atmos. Chem. Phys., 10, 2655-2662, doi:10.5194/acp-102655-2010, 2010.

Lokupitiya, E., Denning, S., Paustian, K., Baker, I., Schaefer, K., Verma, S., Meyers, T., Bernacchi, C. J., Suyker, A., and Fischer, M.: Incorporation of crop phenology in Simple Biosphere Model (SiBcrop) to improve land-atmosphere carbon exchanges from croplands, Biogeosciences, 6, 969-986, doi:10.5194/bg-6969-2009, 2009.

Machida, T., Matsueda, H., Sawa, Y., Nakagawa, Y., Hirotani, K., Kondo, N., Goto, K., Nakazawa, T., Ishikawa, K., and Ogawa, T.: Worldwide measurements of atmospheric $\mathrm{CO}_{2}$ and other trace gas species using commercial airlines, J. Atmos. Ocean. Tech., 25, 1744-1754, 2008.

Machida, T., Katsumata, K., Tohjima, Y., Watai, T., and Mukai, H.: Preparing and maintaining of $\mathrm{CO}_{2}$ calibration scale, in: National Institute for Environmental Studies - NIES $95 \mathrm{CO}_{2}$ Scale, WMO/GAW Report No. 186, edited by: by: Laurila, T., Geneva, 26-29, 2009.

Malhi, Y., Saatchi, S., Girardin, C., and Aragao, L. E. O. C.: The production, storage, and flow of carbon in Amazonian forests, in: Amazonia and Global Change, Geophysical Monograph Series, 
edited by: Keller, M., Bustamante, M., Gash, J., and Silva Dias, P., American Geophysical Union, Washington DC, USA, 186, 355-372, 2009.

Masarie, K., Langenfelds, R. L., Allison, C. E., Conway, T. J., Dlugokencky, E. J., Francey, R. J., Novelli, P. C., Steele, L. P., Tans, P. P., Vaughn, B., and White, J. W. C.: NOAA/CSIRO flask air intercomparison experiment: a strategy for directly assessing consistency among atmospheric measurements made by independent laboratories, J. Geophys. Res., 106(D17), 2044520464, 2001.

Matsueda, H., Inoue, H. Y., and Ishii, M.: Aircraft observation of carbon dioxide at $8-13 \mathrm{~km}$ altitude over the Western Pacific from 1993 to 1999, Tellus B, 54, 1-21, 2002.

Matsueda, H., Machida, T., Sawa, Y., Nakagawa, Y., Hirotani, K., Ikeda, H., Kondo, N., and Goto, K.: Evaluation of atmospheric $\mathrm{CO}_{2}$ measurements from new flask air sampling of JAL airliner observations, Pap. Meteorol. Geophys., 59, 1-17, 2008.

Nevison, C. D., Weiss, R. F., and Erickson III, D. J.: Global oceanic emissions of nitrous oxide, J. Geophys. Res., 100(C8), 1580915820, 1995.

Niwa, Y., Patra, P. K., Sawa, Y., Machida, T., Matsueda, H., Belikov, D., Maki, T., Ikegami, M., Imasu, R., Maksyutov, S., Oda, T., Satoh, M., and Takigawa, M.: Three dimemsional variations of atmospheric $\mathrm{CO}_{2}$ : aircraft measurements and multitransport model simulations, Atmos. Chem. Phys. Discuss., 11, 12805-12848, doi:10.5194/acpd-11-12805-2011, 2011.

Numaguti, A., Takahashi, M., Nakajima, T., and Sumi, A.: Development of CCSR/NIES atmospheric general circulation model, in: Reports of a New Program for Creative Basic Research Studies, CGERs Supercomput. Monogr. Rep., 3, CGER, Tsukuba, Ibaraki, 1-48, 1997.

Olivier, J. G. J. and Berdowski, J. J. M.: Global emissions sources and sinks, in: The Climate System, edited by: Berdowski, J., Guicherit, R., and Heij, B. J., A. A. Balkema Publishers/Swets and Zeitlinger Pub., Lisse, The Netherlands, ISBN 9058092550 , 33-78, 2001.

Pacala, S. W., Hurtt, G. C., Baker, D., Peylin, P., Houghton, R. A., Birdsey, R. A., Heath, L., Sundquist, E. T., Stallard, R. F., Ciais, P., Moorcroft, P., Caspersen, J. P., Shevliakova, E., Moore, B., Kohlmaie, G., Holland, E., Gloor, M., Harmon, M. E., Fan, S.M., Sarmiento, J. L., Goodale, C. L., Schimel, D., and Field, C. B.: Consistent land- and atmosphere-based US carbon sink estimates, Science, 292, 2316-2320, 2001.

Park, M., Randel, W. J., Gettelman, A., Massie, S. T., and Jiang, J. H.: Transport above the Asian summer monsoon anticyclone inferred from Aura Microwave Limb Sounder tracers, J. Geophys. Res., 112, D16309, doi:10.1029/2006JD008294, 2007.

Parthasarathy, B., Munot, A. A., and Kothawale, D. R.: All-India monthly and seasonal rainfall series: 1871-1993, Theor. Appl. Climatol., 49, 217-224, 1994.

Patra, P. K., Ishizawa, M., Maksyutov, S., Nakazawa, T., and Inoue, G.: Role of biomass burning and climate anomalies for land-atmosphere carbon fluxes based on inverse modeling of atmospheric $\mathrm{CO}_{2}$, Global Biogeochem. Cy., 19, GB3005, doi:10.1029/2004GB002258, 2005.

Patra, P. K., Takigawa, M., Dutton, G. S., Uhse, K., Ishijima, K., Lintner, B. R., Miyazaki, K., and Elkins, J. W.: Transport mechanisms for synoptic, seasonal and interannual $\mathrm{SF}_{6}$ variations and "age" of air in troposphere, Atmos. Chem. Phys., 9, 1209-1225, doi:10.5194/acp-9-1209-2009, 2009a.

Patra, P. K., Takigawa, M., Ishijima, K., Choi, B.-C., Cunnold, D., Dlugokencky, E. J., Fraser, P., Gomez-Pelaez, A.J., Goo, T.-Y., Kim, J.-S., Krummel, P., Langenfelds, R., Meinhardt, F., Mukai, H., O’Doherty, S., Prinn, R. G., Simmonds, P., Steele, P., Tohjima, Y., Tsuboi, K., Uhse, K., Weiss, R., Worthy, D., and Nakazawa, T.: Growth rate, seasonal, synoptic, diurnal variations and budget of methane in lower atmosphere, J. Meteorol. Soc. Jpn., 87, 635-663, 2009b.

Piao, S. L., Fang, J., Ciais, P., Peylin, P., Huang, Y., Sitch, S., and Wang, T.: The carbon balance of terrestrial ecosystems in China, Nature, 458, 1009-1013, 2009.

Pisharoty, P. R. and Desai, B. N.: Western disturbances and Indian weather, Indian J. Meteorol. Geophys., 8, 333-338, 1956.

Rayner, P. J., Law, R. M., Allison, C. E., Francey, R. J., Trudinger, C. M., and Pickett-Heaps, C.: Interannual variability of the global carbon cycle (1992-2005) inferred by inversion of atmospheric $\mathrm{CO}_{2}$ and ${ }^{13} \mathrm{CO}_{2}$ measurements, Global Biogeochem. Cy., 22, GB3008, doi:10.1029/2007GB003068, 2008.

Randerson, J., Thompson, M., Conway, T., Fung, I., and Field, C.: The contribution of terrestrial sources and sinks to trends in the seasonal cycle of atmospheric carbon dioxide, Global Biogeochem. Cy., 11(4), 535-560, 1997.

Sander, S. P., Friedl, R. R., Golden, D. M., Kurylo, M. J., Moortgat, G. K., Keller-Rudek, H., Wine, P. H., Ravishankara, A. R., Kolb, C. E., Molina, M. J., Finlayson-Pitts, B. J., Huie, R. E., and Orkin, V. L.: Chemical Kinetics and Photochemical Data for Use in Atmospheric Studies: Evaluation Number 15, JPL Publ. 06-2, Jet Propul. Lab., Calif. Inst. of Technol., Pasadena, USA, 2006.

Schuck, T. J., Brenninkmeijer, C. A. M., Slemr, F., Xueref-Remy, I., and Zahn, A.: Greenhouse gas analysis of air samples collected onboard the CARIBIC passenger aircraft, Atmos. Meas. Tech. 2, 449-464, doi:10.5194/amt-2-449-2009, 2009.

Schuck, T. J., Brenninkmeijer, C. A. M., Baker, A. K., Slemr, F., von Velthoven, P. F. J., and Zahn, A.: Greenhouse gas relationships in the Indian summer monsoon plume measured by the CARIBIC passenger aircraft, Atmos. Chem. Phys., 10, 39653984, doi:10.5194/acp-10-3965-2010, 2010.

Schulze, E. D., Ciais, P., Luyssaert, S., Schrumpf, M., Janssens, I. A., Thiruchittampalam, B., Theloke, J., Saurat, M., Bringeze, S., Lelieveld, J., Lohila, A., Rebmann, C., Jung, M., Bastviken, D., Abril, G., Grassi, G., Leip, A., Freibauer, A., Kutsch, W., Don, A., Nieschulze, J., Borner, A., Gash, J. H., and Dolman, A. J.: The European carbon balance, Part 4: Integration of carbon and other trace-gas fluxes, Glob. Change Biol., 16, 1451-1469, 2010.

Stephens, B. B., Gurney, K. R., Tans, P. P., Sweeney, C., Peters, W., Bruhwiler, L., Ciais, P., Ramonet, M., Bousquet, P., Nakazawa, T., Aoki, S., Machida, T., Inoue, G., Vinnichenko, N., Lloyd, J., Jordan, A., Heimann, M., Shibistova, O., Langenfelds, R. L., Steele, L. P., Francey, R. J., and Denning, A. S.: Weak northern and strong tropical land carbon uptake from vertical profiles of atmospheric $\mathrm{CO}_{2}$, Science, 316, 1732-1735, 2007.

Takahashi, T., Sutherland, S. C., Sweeney, C., Poisson, A., Metzl, N., Tilbrook, B., Bates, N., Wanninkhof, R., Feely, R. A., Sabine, C., Olafsson, J., and Nojiri, Y.: Global sea-air $\mathrm{CO}_{2}$ flux based on climatological surface ocean $p \mathrm{CO}_{2}$, and seasonal biological and temperature effects, Deep-Sea Res. Pt. II, 49, 1601$1622,2002$. 
WDCGG: WMO World Data Centre for Greenhouse Gases, Japan Meteorological Agency, Tokyo, available online at: http://gaw. kishou.go.jp, (last access: 19 April 2010), 2010.

Xiong, X., Houweling, S., Wei, J., Maddy, E., Sun, F., and Barnet, C.: Methane plume over south Asia during the monsoon season: satellite observation and model simulation, Atmos. Chem. Phys., 9, 783-794, doi:10.5194/acp-9-783-2009, 2009.
Yang, X., Richardson, T. K., and Jain, A. K.: Contributions of secondary forest and nitrogen dynamics to terrestrial carbon uptake, Biogeosciences, 7, 3041-3050, doi:10.5194/bg-7-30412010, 2010. 